\title{
Soil-app: a tool for soil analysis interpretation
}

Filipe Inácio Matias ${ }^{1}{ }^{\circledR}$, José Felipe Gonzaga Sabadin ${ }^{1}{ }^{(0}$, Lílian Angélica Moreira ${ }^{2}{ }^{(}$, Marcos Henrique Feresin Gomes $^{3}$, Acácio Bezerra de Mira ${ }^{2}$, Roberto Fritsche-Neto ${ }^{*}{ }^{*}$, Rafael Otto ${ }^{2}$

'Universidade de São Paulo/ESALQ - Depto. de Genética, Av. Pádua Dias, 11 - 13418-900 - Piracicaba, SP -

Brasil.

UUniversidade de São Paulo/ESALQ - Depto. de Ciência do Solo, Av. Pádua Dias, 11 - 13418-900 - Piracicaba, SP Brasil.

3Universidade de São Paulo/CENA, Av. Centenário, 303 13400-970 - Piracicaba, SP - Brasil.

*Corresponding author <roberto.neto@usp.br>

Edited by: Paulo Cesar Sentelhas

Received April 18, 2019

Accepted June 22, 2019
ABSTRACT: New apps have changed the traditional way of learning and teaching; they are also applied as a quickly executed and effective method in agriculture. Soil-app is a web application with a friendly click-point interface built through packages lodged in R software. The app is an advanced model of an open-source platform to support teaching and learning activities in soil analyses and fertilizer recommendations. Soil-app includes soil test interpretation, soil amendment calculations (lime and gypsum), the fertilizer rate for the most important crops in Brazil, an NPK blend calculator, and NPK blend evaluation. It also includes experimental statistical analysis as applied to soil science. Soil-app is a user-friendly and high-performance tool, garnering fast adoption by both students and professionals. It is available for network use through the following link: http://www.genetica.esalq.usp.br/alogamas/R.html

Keywords: software, fertilizers, recommendation, prediction, statistical analyses

\section{Introduction}

Correct interpretation of soil tests is required if soil acidity correction and fertilizer recommendations are to be successful. Crop yield depends on the nutrient balance which is related to the availability of nutrients and their interaction in the soil solution (Wu and $\mathrm{Ma}, 2015$ ).

New software and tools have been developed in Brazil and other parts of the world, demonstrating the need for more user-friendly, low-cost, and easily accessible information regarding management of soil fertility and plant nutrition. FertFacil was developed for the southern region of Brazil for the nutritional interpretation of maize, wheat, and soybean (FertFacil, 2018). Fértil Agrowin is a software system used in the interpretation of plant and soil analysis (Agrotis, 2003), while the FOS (Fertilizer Optimization System) can be used for fertilizer recommendations and the cost of fertilization (Tieppo et al., 2010). These tools are not yet used as agents to promote the learning and teaching process for students on agronomy courses but will become more important in the coming years. Our approach allows students to improve their knowledge through the evaluation of many hypothetical scenarios and of how parameters may influence each other and the final scenario.

The main goal was to develop a user-friendly and open-source application through the Shiny package in the $\mathrm{R}$ software program. Our webapp comprises the following modules: physical and chemical soil test interpretation, different methods of liming and gypsum recommendation, NPK fertilizer recommendation, soil amendment scenario simulation, and statistical analysis tools for experiments in soil science.

\section{Materials and Methods}

Soil-app has sections divided by different subjects related to soil tests and soil fertility. The methods and models used in each section are described below:

\section{Unit conversion}

The International System of Units admits several derivations of the standards. Soil test interpretation and fertilizer recommendation require units to be standardized. Over the years, several changes in the units used have been adopted by professionals to make results easier to understand. Transformations used in the application were implemented based on chemical stoichiometry and information provided by Raij et al. (1997) and Ribeiro et al. (1999).

\section{Soil test interpretation}

Interpretation of soil test results is crucial to an understanding of which soil nutrients are inadequate and how much should be applied to meet plant demand (Cantarutti et al., 2007). The app allows for interpretation of soil chemical and physical test results, classifying the nutrient content as very low, low, medium, high, or very high, as well as physical characterization driven by clay content (Raij et al., 1997).

\section{Fertilizers}

Fertilizer recommendation in Brazil is based upon regional studies of soil test calibration and response curves. Doses are defined according to soil nutrient content and expected yield (Cantarutti et al., 2007). Soil-app offers alternative fertilizer recommendation since it approaches the specific need 
for each nutrient and promotes the use of raw material as well as fertilizer blends. Fertilizer recommendation can be formulated for crops such as grains (i.e., soybean, corn, beans), pastures, forage, and forest. The fertilizer recommendation function of Soil-app is based on data presented by Raij et al. (1997) and Ribeiro et al. (1999). Soil-app can be optimized in the future following the release of new bulletins or recommendation methods.

\section{Organic fertilizers}

The use of organic fertilizers is a useful technique for nutrient supply, promoting environmental gains with the potential to improve the sustainability of agricultural systems, especially in soils with low organic matter and nutrient contents (Santos et al., 2008). However, the use of organic fertilizer is limited by a lack of knowledge, especially relating to dose calculation which is based on the nutrient content of the organic material and moisture content. The app presents an average nutrient content for common sources based on Raij et al. (1997) as well as a tool for converting values from dry weight concentration which comes from chemical analysis to the current wet weight, as per the equation below:

Wet weight content $=\frac{(100-\text { moisture content }(\%))}{100} \times$ dry weight content

\section{Liming}

Acidic soils are common in both tropical and subtropical regions. Soil nutrient availability to plants depends on soil $\mathrm{pH}$, which has an impact on fertilizer efficiency (Behera and Shukla, 2015). Liming is the primary method used to raise soil $\mathrm{pH}$ and meet the demand for calcium and magnesium for plants (Caires et al., 2011b). The most widespread methods of liming adopted in Brazil are currently presented in Boletim 100 (Raij et al., 1997) and $5^{\text {a }}$ Aproximação (Ribeiro et al., 1999).

In Boletim 100 (Raij et al., 1997), lime recommendation is based on increasing base saturation to target values dependent on crop demand. In the $5^{\text {a }}$ Aproximação (Ribeiro et al., 1999), the recommendation method is based on increasing soil $\mathrm{Ca}$ and $\mathrm{Mg}$ content, as well as $\mathrm{Al}$ neutralization. The amount of lime recommended (QC) should be adjusted as regards tilling depth $(\mathrm{PF})$, relative total neutralization power (PRNT), and application area (AS) as described in the equation below:

$Q C=N C \times \frac{P F}{20} \times \frac{A S}{100} \times \frac{100}{P R N T}$

For example, if the necessity for liming is $2 \mathrm{t}$ $\mathrm{ha}^{-1}$, it will be applied over the total area $(\mathrm{AS}=100$ $\%)$ and tilled in the first $20 \mathrm{~cm}$ of soil depth (PF $=20$ $\mathrm{cm})$. If the limestone has PRNT equal to $95 \%$, then the recommended amount of limestone to be applied is QC $=2.105 \mathrm{t} \mathrm{ha}^{-1}$.

\section{Gypsum}

Agricultural gypsum is used to reduce the toxic $\mathrm{Al}^{3+}$ availability to plant roots in low-fertility soils, contributing to proper plant development and higher yields (Caires et al., 2011a). Many equations are available in Brazil to fix the recommended gypsum doses, based on soil subsurface $(20-40 \mathrm{~cm})$ chemical and physical characteristics. The gypsum recommendation (NG) has been reported by Raij et al. (1997) where the NG = clay content $\times 60$, which considers the percentage of soil clay content (\% clay). The equation is similar to that of Ribeiro et al. (1999), which considers soil texture $(\mathrm{X})$ in the equation $\mathrm{NG}=\left(0.00034-0.00244 \mathrm{X}^{0.5}\right.$ $\left.+0.0338886 \mathrm{X}-0.00176366 \mathrm{X}^{1.5}\right) \times 1000$. Also, it is possible to consider the $\mathrm{P}_{\text {rem }}$ (remaining phosphorous) as in the equation

$N G=\left(315.8-25.5066 P_{\text {rem }}^{0.5}-5.70675 P_{\text {rem }}+0.485335 P_{\text {rem }}^{1.5}\right) \times \frac{1000}{\% C a_{\text {gypsum }}}$.

Another important method is the EMBRAPA recommendation wherein $\mathrm{NG}=$ clay content $\times 50$ for annual crops and NG = clay content $\times 75$ for perennial crops (Sousa and Lobato, 2004). The most recent recommendation for gypsum application, developed by Caires and Guimarães (2018), is based on the increase in calcium saturation at the effective cation exchange capacity $\left(\mathrm{CEC}_{\mathrm{e}}\right)$ as in the following equation: $\mathrm{NG}=10.6$ $\times \mathrm{CEC}_{\mathrm{e}}-\mathrm{Ca}$ content) $\times$ 640, where the Ca content is the amount of $\mathrm{Ca}$ in the subsoil (0.2-0.4 $\mathrm{m}$ soil depth). Coefficients were added to the equations to provide recommendations in $\mathrm{kg} \mathrm{ha}^{-1}$.

\section{Broadcast $\mathbf{P}$ application}

Tropical soils naturally present a low $\mathrm{P}$ content and high adsorption capacity of the clay fraction which reduces $\mathrm{P}$ availability (Novais and Smith, 1999). Noncultivated soils usually present a very low $\mathrm{P}$ content. Increasing $\mathrm{P}$ content in the first year of agriculture, through broadcast application of $\mathrm{P}$ fertilizers, will promote better root growth, and increase yield potential and profitability in the first years of cultivation (Sousa and Lobato, 2004). After increasing the $\mathrm{P}$ content to a target level, and thus improving yield potential, $\mathrm{P}$ fertilization with soluble fertilizers will be performed annually at the time of crop establishment. The app will support users in determining the $\mathrm{P}$ fertilizer rate according to soil $\mathrm{P}$ and clay content as described in Table 1 and the equation below (Sousa et al., 2016). The advantage of the procedure is the use of the two main $\mathrm{P}$ extractants used in Brazil, resin and Mehlich 1.

$\mathrm{P}$ fertilizer demand $\left(\mathrm{kg} \mathrm{ha}^{-1}\right)=$ Critical level $\mathrm{P}_{\text {soil }} \times$ Fixation capacity of the soil

\section{Limit of nutrient content in fertilizers}

There is a wide range of raw materials for fertilizer production, mainly concerning nutrient content and solubility (Alcarde, 2007). Ensuring the physical, chemical, and physical-chemical quality of fertilizers 
Table 1 - Variables used to calculate the P fertilizer demand of the soil (adapted by Sousa et al., 2016).

\begin{tabular}{|c|c|c|c|c|}
\hline \multirow{2}{*}{ Clay Content } & \multicolumn{2}{|c|}{ Critical level of $P$} & \multicolumn{2}{|c|}{ Fixation Capacity of the soil (FC } \\
\hline & Mehlich & Resin & Mehlich & Resin \\
\hline$\%$ & \multicolumn{2}{|c|}{$-\mathrm{mg} \mathrm{dm}^{-3}$} & \multicolumn{2}{|c|}{$\left(\mathrm{kg} \mathrm{P}_{2} \mathrm{O}_{5} \mathrm{ha}^{-1}\right)\left(\mathrm{mg} \mathrm{dm}^{-3} \mathrm{P}\right)^{-1}$} \\
\hline $10-15$ & 20 & 15 & 5 & 6 \\
\hline $16-20$ & 18 & 15 & 6 & 7 \\
\hline $21-25$ & 17 & 15 & 7 & 8 \\
\hline $26-30$ & 15 & 15 & 9 & 9 \\
\hline $31-35$ & 14 & 15 & 11 & 10 \\
\hline $36-40$ & 13 & 15 & 15 & 12 \\
\hline $41-45$ & 11 & 15 & 18 & 13 \\
\hline $46-50$ & 10 & 15 & 23 & 14 \\
\hline $51-55$ & 8 & 15 & 29 & 15 \\
\hline $56-60$ & 7 & 15 & 37 & 16 \\
\hline $61-65$ & 5 & 15 & 54 & 17 \\
\hline $66-70$ & 4 & 15 & 70 & 19 \\
\hline
\end{tabular}

is essential to proper plant development, mostly due to the narrow range between deficiency and toxicity of certain essential elements. The limits of tolerance for nutrient content in NPK fertilizers are defined by the Ministério da Agricultura, Pecuária e Abastecimento MAPA, 2014, (the Ministry of Agriculture, Livestock and Supply) whose legislation is responsible for disseminating the standards and methodologies used to control fertilizer nutrient quantity and quality. With Soil-app, the user can input the analytical result and evaluate if the nutrient content is within accepted regulatory limits.

\section{Simulator}

This section provides the opportunity to explore different scenarios before and after soil amendments or fertilizer application. With this innovation, the user can input soil test data, parameters, and product doses. The app provides two graphics with soil fertility analysis before and after input application. Furthermore, the app predicts $\mathrm{P}, \mathrm{K}, \mathrm{Ca}$, and $\mathrm{Mg}$ soil content after application through equations used to estimate the increase in nutrient content according to Raij et al. (1997). Calculations presented in this section are theoretical and do not consider losses or nutrient transformation in the soil-plant system. Despite this limitation of the app, simulating chemical changes in soil properties is a good exercise for teaching and consulting purposes.

$\mathrm{P}_{\text {increase }}\left(\mathrm{mg} \mathrm{dm}^{-3}\right)=\mathrm{P}_{2} \mathrm{O}_{5}$ dose $\left(\mathrm{kg} \mathrm{ha}^{-1}\right) \times 0.2185$

$\mathrm{K}_{\text {increase }}\left(\mathrm{mmol}_{\mathrm{c}} \mathrm{dm}^{-3}\right)=\mathrm{K}_{2} \mathrm{O}$ dose $\left(\mathrm{kg} \mathrm{ha}^{-1}\right) \times 0.415$

$\mathrm{Ca}_{\text {increase }}\left(\mathrm{mmol}_{\mathrm{c}} \mathrm{dm}^{-3}\right)=$ limestone dose $\left(\mathrm{t} \mathrm{ha}^{-1}\right) \times \mathrm{CaO}$ content $_{\text {limestone }}(\%) \times 0.1785$

$\mathrm{Mg}_{\text {increase }}\left(\mathrm{mmolc} \mathrm{dm}^{-3}\right)=$ limestone dose $\left(\mathrm{t} \mathrm{ha}^{-1}\right) \times \mathrm{MgO}$ content $_{\text {limestone }}(\%) \times 0.2482$

\section{Data analysis}

The Soil-app allows for the running of different data analyses for soil scientists. Scripts in $\mathrm{R}$ were developed to make data analysis faster and handier. Those analyses are in the "Experimental Analysis" ("Análises de Experimentos") section, and are divided into two tabs: "Experimental Designs" ("Delineamentos Experimentais") and "Multivariate Analysis" ("Análise Multivariada"). Each tab has a help button with tutorials that explain data entry and output details. For statistical analysis where data input is required, there are examples of datasets available and the user can get extra information using the help button. The "Experimental Designs" ("Delineamentos Experimentais") tab uses the "lm" and "aov" functions of $\mathrm{R}$ (version 3.4.4, 2018), allowing the user to calculate the analysis of the variance (ANOVA) table through a previously defined statistical model. Furthermore, the "Results" ("Resultados") tab will enable the user to choose the method to fit the $p$-value, calculate Tukey's test (mean comparison), and generate boxplot graphics at the level factors.

The Multivariate Analysis ("Análise Multivariada") section is divided into three other tabs: the first is "Datasets" ("Conjunto de Dados") to input user data. To access data input information, the user should click in the help box inside the tab; the second is the "Correlation" ("Correlação") tab which uses the "cor()" function of $\mathrm{R}$ to estimate the Pearson correlation and "qgraph" (correlation network map) among the traits evaluated; and the third is the "Principal Components" ("Componentes Principais") tab that allows the user to realize PCA (principal components analysis) and PCA biplot graphics based on the two most significant principal components from the user data uploaded.

\section{Results and Discussion}

Soil-app offers a wide variety of soil chemical and physical analysis, lime, gypsum, and fertilizer recommendations, nutrient tolerance content in NPK fertilizers, simulation of scenarios to improve soil fertility, and statistical approaches. The outputs are accessible to be interpreted by a direct and friendly web interface. Furthermore, Soil-app can be used to improve teaching and learning activities, as it does not require programming skills, allowing for fast and full adoption. Soil-app is available for network use through the link: http://www.genetica.esalq.usp.br/ alogamas/R.html

\section{Acknowledgments}

We thank the Conselho Nacional de Desenvolvimento Científico e Tecnológico (CNPq) for financial support. This study was financed in part by the Coordenação de Aperfeiçoamento de Pessoal de Nivel Superior (CAPES) - Finance Code 001. 


\section{Authors' Contributions}

Conceptualization: Matias, F.I.; Sabadin, J.F.G. Data acquisition: Moreira, L.A.; Gomes, M.H.F.; Mira, A.B. de. Data analysis: Matias, F.I.; Sabadin, J.F.G.; Moreira, L.A.; Gomes, M.H.F. Design of methodology: Fritsche-Neto, R.; Otto, R. Software development: Matias, F.I.; Sabadin, J.F.G. Writing and editing: Matias, F.I.; Sabadin, J.F.G.; Moreira, L.A.; Gomes, M.H.F.; Fritsche-Neto, R.; Otto, R.

\section{References}

AGROTIS. 2003. Fertil Agrowin Software for soil analysis interpretation $=$ Fértil Agrowin software para interpretação de análises de solo. Available at: https://www.agrotis.com [Accessed Mar 11, 2019] (in Portuguese)

Alcarde, J.C. 2007. Fertilizers $=$ Fertilizantes. p. 737-768. In: Novais, R.F.; Alvarez, V.H.; Barros, N.F.; Fontes, R.L.F.; Cantarutti, R.B.; Neves, J.C.L., eds. Soil fertility $=$ Fertilidade do solo. SBCS, Viçosa, MG, Brazil (in Portuguese).

Behera, S.K.; Shukla, A.K. 2015. Spatial distribution of surface soil acidity, electrical conductivity, soil organic carbon content and exchangeable potassium, calcium and magnesium in some cropped acid soils of India. Land Degradation and Development 26: 71-79.

Caires, E.F.; Joris, H.A.W.; Churka, S. 2011a. Long-term effects of lime and gypsum additions on no-till corn and soybean yield and soil chemical properties in southern Brazil. Soil Use and Management 27: 45-53.

Caires, E.F.; Maschietto, E.H.G.; Garbuio, F.J.; Churka, S.; Joris, H.A.W. 2011b. Surface application of gypsum in low acidic Oxisol under no-till cropping system. Scientia Agricola 68: 209-216.

Caires, E.F.; Guimarães, A.M. 2018. A novel phosphogypsum application recommendation method under continuous no-till management in Brazil. Agronomy Journal 110: 1987-1995.

Cantarutti, R.B.; Barros, N.F.; Martinez, H.E.P.; Novais, R.F. 2007. Evaluation of soil fertility and fertilizer recommendations $=$ Avaliação da fertilidade do solo e recomendação de fertilizantes. p. 769-850. In: Novais, R.F.; Alvarez, V.H.; Barros, N.F.; Fontes, R.L.F.; Cantarutti, R.B.; Neves, J.C.L., eds. Soil Fertility = Fertilidade do solo. SBCS, Viçosa, MG, Brazil (in Portuguese).
FERTFACIL. 2018. FertFacil. Available at: https://www.fertfacil. com/sistema/ [Accessed Mar 11, 2019] (in Portuguese)

Ministério da Agricultura, Pecuária e Abastecimento [MAPA]. 2014. Manual of Official Analytical Methods for Fertilizers and Liming Materials = Manual de Métodos Analíticos Oficiais para Fertilizantes e Corretivos. MAPA, Brasília, DF, Brazil (in Portuguese).

Raij, B., van; Cantarella, H.; Quaggio, J.A.; Furlani, A.M.C. 1997. Fertilizers and lime recommendations for the state of São Paulo $=$ Recomendação de adubação e calagem para o Estado de São Paulo. 2ed. IAC, Campinas, SP, Brazil (Boletim, 100) (in Portuguese).

Ribeiro, A.C.; Guimarães, P.T.G.; Alvarez, V.H. 1999. Soil amendments and fertilizer recommendations for Minas Gerais: $5^{\text {th }}$ approximation $=$ Recomendações para o uso de corretivos e fertilizantes em Minas Gerais: $5^{\mathrm{a}}$ aproximação. CFSEMG, Viçosa, MG, Brazil (in Portuguese).

Santos, G.A.; Silva, L.S.; Canellas, L.P.; Camargo, F.O. 2008. Fundamentals of the Soil Organic Matter: Tropical \& Subtropical Ecosystems = Fundamentos da Matéria Orgânica do Solo: Ecossistemas Tropicais \& Subtropicais. 2ed. Embrapa Arroz e Feijão, Santo Antônio de Goiás, GO, Brazil (in Portuguese).

Sousa, D.M.G.; Lobato, E. 2004. Cerrado: soil amendments and fertilization = Cerrado: correção do solo e adubação. 2ed. Embrapa Informações Tecnológicas, Brasília, DF, Brazil (in Portuguese).

Sousa, D.M.G.; Rein, T.A.; Santos Jr., J.D.G. 2016. P fertilization management in annuals crops at Cerrado $=$ Manejo da adubação fosfatada para culturas anuais no cerrado. Embrapa Cerrados, Planaltina, DF, Brazil (Circular Técnica, 33) (in Portuguese).

Tieppo, R.C.; Cremon, C.; Silva, L.C.; Dallacort, R.; Santi, A. 2010. Computational system for fertilizer selection optimization. Scientia Plena 6: 1-4 (in Portuguese, with abstract in English).

Wu, W.; Ma, B.-L. 2015. Integrated nutrient management (INM) for sustaining crop productivity and reducing environmental impact: a review. Science of the Total Environment 512-513: 415-427. 